\title{
The role of hydrological and spatial factors for the vegetation of Central European springs
}

\author{
Volker AUDORFF*, Jutta KAPFER ${ }^{1)}$ and Carl BEIERKUHNLEIN \\ University of Bayreuth, Bayreuth Center of Ecology and Environmental Research BayCEER, Department of Biogeography, \\ Universitätsstraße 30, 95440 Bayreuth, Germany \\ ${ }^{1)}$ University of Bergen, Department of Biology, Thormøhlensgate 53A, 5008 Bergen, Norway \\ *e-mail corresponding author: volker.audorff@uni-bayreuth.de
}

\begin{abstract}
Understanding the driving forces affecting species occurrences is a prerequisite for determining the indicator suitability of crenic plants. We analysed 18 environmental variables in a two-step approach, evaluating their ability to explain the species composition of 222 springs on five siliceous mountain ranges, in central Germany and north-west Czech Republic (49.9 $-50.8^{\circ} \mathrm{N}$, $10.6^{\circ}-12.8^{\circ} \mathrm{E}$ ). First, we identified the significant environmental variables in three subsets of spatial, hydrophysical and hydrochemical variables using a forward-selection procedure. We then performed a partial canonical correspondence analysis ( $\mathrm{CCCA}$ ) to estimate the influence of each subset alone, as well as in combinations. We also used a multiple response permutation procedure (MRPP) to compare the five regions with respect to the dissimilarity of their vegetation composition and environmental variables. Hydrochemical factors played a fundamental role in determining the plant community of the investigated springs. Spatial factors, in particular altitude, were correlated with the hydrochemical factors, but were less important. Hydrophysical factors played only a marginal role. More precisely, species occurrence was mainly driven by a gradient of nutrient availability, which in turn reflected the acidity status. This gradient was primarily represented by high $\mathrm{Al}, \mathrm{Cd}$, and $\mathrm{Mn}$ concentrations in acidic crenic waters, high $\mathrm{Ca}$ and $\mathrm{Mg}$ concentrations were encountered in circumneutral springs. By comparing the five regions we could show that there are spatial patterns in the vegetation of springs, which provide valuable ecological information on the water quality. We therefore suggest that biomonitoring approaches to vegetation are suitable for revealing the acidity status of springs and their forested catchments.
\end{abstract}

Key words: biomonitoring, partial canonical correspondence analysis pCCA, species composition, spring water hydrochemistry, vegetation ecology

\section{INTRODUCTION}

Springs provide a habitat for specialised organisms that are adapted to the relatively constant environment (Thienemann 1924; Odum 1971; Ellenberg 1996). Most crenobiontic and crenophilous species are stenoecious (Ferrington 1998; Zollhöfer et al. 2000; Cantonati et al. 2006). Hence, the species composition of springs clearly differs from the adjacent ecosystems, in which the short-term and seasonal variability in the environment is more pronounced. The majority of crenic communities were never directly impacted or modified by land use or other disturbances, but their ecosystem functioning is still dominated by natural drivers. As a result species composition could adapt to the physical and chemical properties of crenic waters over long time periods. But, there are additional attributes of springs which make them interesting subjects in which to study species-environment relationships.

Helocrenic springs are surrounded by habitats with disparate conditions. They resemble islets with specific habitat conditions unrelated to their surroundings. As the ecological distinctness, and particularly thermal constancy, is reduced in the proximate mountain brook, springs show considerable ecological isolation. Direct spatial connectivity is negligible. Together with the natural constancy of hydrological factors, this allows species occurrences to be related to environmental conditions.

In the investigated Central European siliceous mountain ranges groundwater is mainly transported in surface-near aquifers (interflow; Kleber et al. 1998) and closely reflects the biogeochemical and hydrological status of the catchments (Beierkuhnlein \& Durka 1993). Thus, springs reflect the hydrological output of an ecosystem in a spatially concentrated manner. In our approach, forest ecosystem catchments were regarded as black boxes. The 'small catchment approach' (e.g., Moldan \& Černý 1994; Church 1997; Likens \& Bormann 1999) applies to springs.

As water flow in springs is unidirectional and continuous, the crenic organisms are expected to depend strongly on the quantity and quality of the emerging groundwater. Crenic water chemistry, in particular the gradient of acidity and nutrient availability, has been discussed as the major driving factor for the vegetational composition of siliceous forest springs (Beierkuhnlein 1994; Hájek et al. 2002; Hájková et al. 2008). Other site conditions, such as the mesoclimate of the forest ecosystem itself and various catchment parameters, have been found to be less important for 


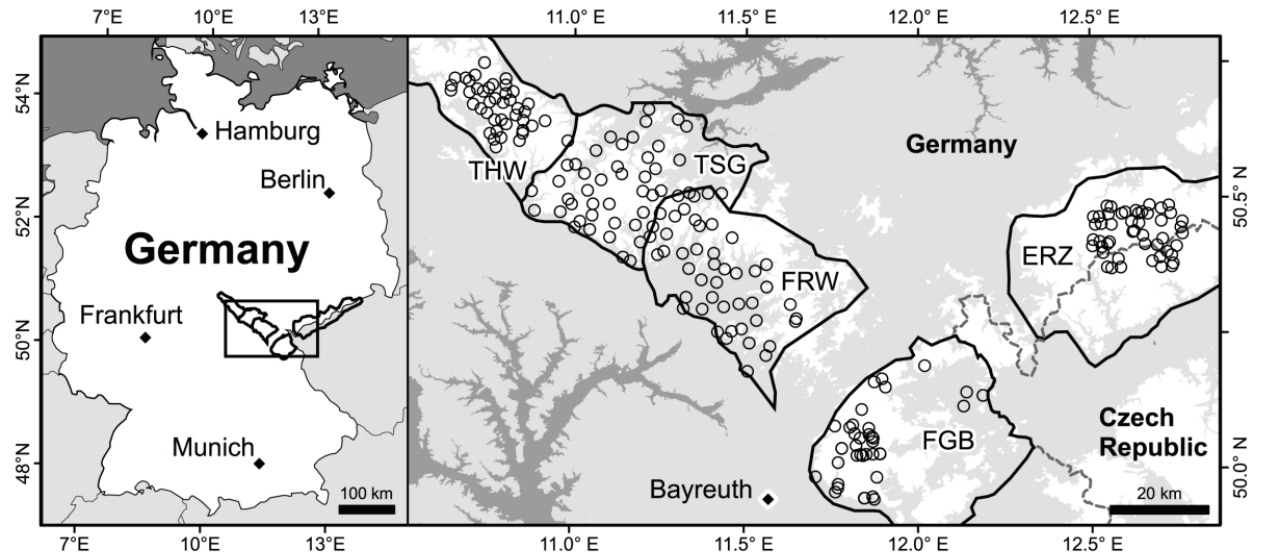

Legend

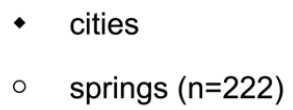

altitude a.s.l.

study areas

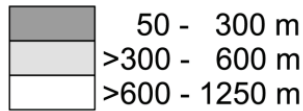

Fig. 1. Maps showing the locations of the investigated springs $(n=222)$ and monitored landscapes in central Germany and the north west Czech Republic. Abbreviations denote the five regions: THW = Thüringer Wald, TSG $=$ Thüringer Schiefergebirge, FRW $=$ Frankenwald, FGB $=$ Fichtelgebirge and ERZ $=$ Erzgebirge.

Tab. 1. Landscape features of the five studied regions.

\begin{tabular}{lcccccc}
\hline region & $\begin{array}{c}\text { Thüringer } \\
\text { Wald }\end{array}$ & $\begin{array}{c}\text { Thüringer } \\
\text { Schiefergebirge }\end{array}$ & $\begin{array}{c}\text { Franken- } \\
\text { wald }\end{array}$ & $\begin{array}{c}\text { Fichtel- } \\
\text { gebirge }\end{array}$ & $\begin{array}{c}\text { Erz- } \\
\text { gebirge }\end{array}$ & $\begin{array}{c}\text { all five } \\
\text { regions }\end{array}$ \\
\hline $\begin{array}{l}\text { landscape trait } \\
\text { altitude a.s.1. }[\mathrm{m}] \\
\text { predominant } \\
\text { bedrock }\end{array}$ & $\begin{array}{c}300-980 \\
\text { porphyry, } \\
\text { mean annual } \\
\text { precipitation }\left[\mathrm{mm} \mathrm{y}^{-1}\right]\end{array}$ & $\begin{array}{c}250-870 \\
\text { schist, } \\
\text { quarzite }\end{array}$ & $\begin{array}{c}350-790 \\
\text { schist }\end{array}$ & $\begin{array}{c}450-1050 \\
\text { granite, } \\
\text { phyllite }\end{array}$ & $\begin{array}{c}400-1240 \\
\text { granite, gneiss } \\
\text { phyllite }\end{array}$ & $\begin{array}{c}250-1240 \\
\text { siliceous }\end{array}$ \\
$\begin{array}{c}\text { mean annual } \\
\text { air temperature }\left[{ }^{\circ} \mathrm{C}\right]\end{array}$ & $800-1200$ & $550-1200$ & $600-1000$ & $600-1350$ & $700-1200$ & $550-1350$ \\
$\begin{array}{c}\text { dominating } \\
\text { tree species }\end{array}$ & $\begin{array}{c}\text { Picea abies, } \\
\text { (Fagus sylv.) }\end{array}$ & $\begin{array}{c}\text { Picea abies, } \\
\text { (Fagus sylv. })\end{array}$ & $\begin{array}{c}\text { Picea abies, } \\
\text { (Fagus sylv. })\end{array}$ & Picea abies & Picea abies & $\begin{array}{c}\text { Picea abies, } \\
(\text { Fagus sylv. })\end{array}$ \\
\hline
\end{tabular}

species composition than hydrochemical variables (Strohbach et al. 2009). In this study we therefore concentrate on the environmental variables measured at the crenic site, but over a study area of five siliceous mountain ranges in Central Europe.

Our aim is to describe the vegetational composition of springs and its relationship to hydrophysical, hydrochemical and spatial variables across a large area of predominantly forested landscapes. We hypothesize that water chemistry, especially the acidity status of the water, is the major determining factor for the occurrence of crenic plant species, and for its community composition.

Although springs occupy only a small proportion of the land surface, they appear frequently in forested mountain ranges of Central Europe. Their abundance makes them suitable subjects for monitoring purposes at the landscape scale, offering a high spatial resolution of comparable and almost standardised records (Beierkuhnlein \& Durka 1993).

Summing up the above-mentioned points, the distinctiveness of springs and the species in them, qualify such habitats for biomonitoring approaches. In par- ticular, the biogeochemical status of forest ecosystems, related to the deposition of acidifying compounds, can be detected. When comparing several regions, patterns at the landscape scale are expected to emerge. In addition to the availability of highly sensitive organisms, the clear localisation and balanced physical conditions are excellent prerequisites for the biomonitoring of the biogeochemical status of springs and their catchments.

\section{METHODS}

\subsection{Study area and study sites}

We investigated vegetation and environmental variables in springs in five neighbouring mountain ranges: Thüringer Wald, Thüringer Schiefergebirge, Frankenwald, Fichtelgebirge and Erzgebirge. These landscapes are located in central Germany and the north west of the Czech Republic (Fig. 1). Altitude ranges between 250 and $1240 \mathrm{~m}$ a.s.l. and bedrock material consists of silicates throughout, and is relatively homogeneous in each region. Climatic conditions are at the transition from oceanic to continental. Detailed landscape characteristics are given in table 1 . The study areas are pre- 
dominantly covered by forest and were exposed to severe acid deposition, culminating in the 1970s and 1980s. These loads resulted in the acidification of ground-, spring-, and headwaters. Mountain lakes and ponds were also affected (e.g., Reuss et al. 1987; Steinberg \& Wright 1994). As historical mining activities may blur catchment traits and the hydrochemical properties of headwaters (Peiffer et al. 1997), such areas were excluded a priori from our study.

In our study areas the springs are generally helocrenic springs (sensu Thienemann 1924), with a saturated area of a few to some hundred square meters, where water seeps out continuously from the ground. The discharge rates are usually low $\left(<2.0 \mathrm{~L} \mathrm{~s}^{-1}\right)$, but there are some seasonal fluctuations, depending on climate and the size of the catchment. The crenic water temperatures, and consequently the near-surface air temperatures too, are equilibrated in the springs by the permanent energy supply of the groundwater.

We initially investigated 251 springs, but 29 had to be omitted due to insufficient discharge $\left(<0.02 \mathrm{~L} \mathrm{~s}^{-1}\right)$ and missing values in the hydrological dataset. Hence 222 springs remained for the analyses. All these springs and their catchments are located in forests, mainly dominated by Norway spruce (Picea abies), but also partly by beech (Fagus sylvatica). The altitude of the sites ranges from 270 to $925 \mathrm{~m}$ a.s.l., the $\mathrm{pH}$ of the siliceous, nutrient-poor crenic waters is acidic to neutral.

\subsection{Sampling of environmental and vegetation data}

In vegetation relevés we estimated the abundance/dominance scores of all vascular plants, mosses and liverworts growing over the entire, well-differentiated seepage area. This was carried out, either in July or in August, using the Braun-Blanquet (1964) method, but with a slightly modified scale (see Tab. 2). Nomenclature follows Frahm \& Frey (2004) for bryophytes and Oberdorfer (2001) for vascular plants.

Tab. 2. Modified Braun-Blanquet's abundance/dominance scores and the codes used for statistical analyses.

\begin{tabular}{ccc}
\hline $\begin{array}{c}\text { Br.-Bl. } \\
\text { score }\end{array}$ & $\begin{array}{c}\text { Cover } \\
{[\%]}\end{array}$ & Code \\
\hline $\mathrm{r}$ & $0-0.01$ & 0.1 \\
+ & $0.01-0.2$ & 0.5 \\
1 & $0.2-5$ & 2.5 \\
$2 \mathrm{a}$ & $5-15$ & 10.0 \\
$2 \mathrm{~b}$ & $15-25$ & 20.0 \\
3 & $25-50$ & 37.5 \\
4 & $50-75$ & 62.5 \\
5 & $75-100$ & 87.5 \\
\hline
\end{tabular}

Environmental data were collected under three categories, hydrophysical $(n=2)$, hydrochemical $(n=$ $13)$ and spatial $(n=3)$ variables. Water was sampled in late September and October, always at the uppermost point of the seepage area with above ground flowing water. Before measurements were taken, a small pit was formed and the water was allowed to clear.

We measured the hydrophysical variables, discharge and electrical conductivity, as well as the hydrochemical variable, $\mathrm{pH}$, in situ. The hydrochemical variable, acid neutralising capacity (ANC) was estimated in vitro, by titration with $0.1 \mathrm{M} \mathrm{HCl}$ to $\mathrm{pH}$ 4.3. Water was analysed for the hydrochemical compounds, $\mathrm{NH}_{4}^{+}, \mathrm{NO}_{3}^{-}, \mathrm{SO}_{4}{ }^{2-}, \mathrm{PO}_{4}{ }^{3-}$, and the elements, $\mathrm{Ca}, \mathrm{Mg}, \mathrm{K}, \mathrm{Mn}, \mathrm{Al}, \mathrm{Cd}, \mathrm{Na}$. The spatial variables, latitude, longitude and altitude, were derived from topographic maps. Space, of course, is not a driver of ecological relations, but can be used to represent spatial factors and processes (Leduc et al. 1992). The hydrophysical variable, water temperature, was not included in the analyses because data were not available for the Thüringer Schiefergebirge.

We summarised data from the five regions since all these regions were surveyed using the same sampling protocol and analytical methods. However, the investigations were conducted in different years (Thüringer Schiefergebirge 1993; Thüringer Wald \& Erzgebirge 1997; Frankenwald \& Fichtelgebirge 2003). Nevertheless, because our main focus is to identify the driving forces of community composition, we assumed that this inconsistency was not important here.

\subsection{Statistical analyses}

Initially, to obtain an overview of the hydrological characteristics of crenic waters, all environmental data were examined by linear correlation analysis, using Pearson's coefficient.

Determinant factors of species composition in springs were determined using a canonical analysis of vegetation and environmental data. Braun-Blanquet's abundance/dominance scores of the remaining species were converted into percentage cover (for code replacement see Tab. 2) and square-root transformed to down-weight dominant and up-weight rare species, as Legendre \& Gallagher (2001) recommend for comparing communities to environmental data. Environmental variables, except for $\mathrm{pH}$, acid neutralizing capacity (ANC) and the spatial variables (longitude, latitude and altitude), were logarithmically transformed. We therefore substituted elemental and compound concentrations below the limit of quantitation (LOQ) by $0.5 \times \mathrm{LOQ}$. $\mathrm{pH}$ is already a negative logarithmic value of hydrogen ion concentration. As ANC includes zero values, a square root transformation was chosen for this variable. Spatial variables were not transformed.

We chose a two-step approach to reveal the driving forces behind plant community composition. First, we ran a forward-selection (cf. Oksanen 2009) using standard $\mathrm{R}$ function step() for automatic selection of significant constraints. This was done separately for each of the three environmental variable subsets, hydrophysics, hydrochemistry and space. The canonical 
analysis therefore benefits, because the autocorrelations in the environmental dataset are confined by the preselection of important variables. Based on the preselected variables, we then ran a partial canonical correspondence analysis (pCCA). pCCA is a variance partitioning procedure which allows testing for the effects of a subset of explanatory variables, while partitioning out the effects of another subset of explanatory variables. This analysis was performed to identify the proportion of total variance explained by each of the three environmental variable subsets alone, as well as in all possible combinations.

The subsequent canonical correspondence analysis (CCA) is based on the environmental variables of all three environmental subsets, as chosen by forward-selection.

To test the five regions for significant differences in both vegetation and environment we ran a multiple response permutation procedure (MRPP; R function mrpp(), based on Euclidean distance; 999 permutations). This method is suggested for analysing withinversus among-group dissimilarities for multivariate datasets in a priori groups (McCune \& Grace 2002), in our case, five regions. The variables, latitude and longitude, were excluded from the MRPP analysis of environmental variables in order to avoid spatial bias in the regional comparison.

Because in several other studies acidity and nutrient availability were found to be important determining factors for the species composition in springs (Beierkuhnlein 1994; Hájek et al. 2002; Hájková et al. 2008; Strohbach et al. 2009), we conducted a regression analysis to analyse the relationship between crenic water $\mathrm{pH}$, and the statistically significant correlated hydrochemical variables. Linear model fit was tested by computing an analysis of variance (ANOVA) using $\mathrm{R}$ function anova $(\operatorname{lm}())$.

All analyses were computed in $\mathrm{R}$, version 2.10 .2 ( $\mathrm{R}$ Development Core Team 2009). CCA, pCCA and MRPP were performed using $R$ package vegan, version 1.15-4 (Oksanen et al. 2009). Only species occurring in at least 10 springs were considered in the statistical analyses, reducing the total number of species from 284 to 110 .

\section{RESULTS}

In all five regions, crenic waters are acidic to circumneutral, and can be characterised as nutrient-poor throughout. $\mathrm{pH}$ ranged from 3.76 to 7.80 , and electrical conductivity from 27 to $719 \mu \mathrm{S} \mathrm{cm} \mathrm{cm}^{-1}$. Several hydrophysical and hydrochemical variables differed between the regions. The mean values and ranges of the measured hydrological factors are summarised in table 3 , for each of the regions separately, as well as together. The correlations between the individual environmental variables are shown in table 4.

Using MRPP, low, but significant dissimilarities between the five regions were found for the entirety of the environmental variables (Tab. 5). Environmental conditions in the Erzgebirge differed slightly from those in the Thüringer Schiefergebirge $(\mathrm{A}=0.265 ; p$ $<0.001)$. Relatively strong dissimilarity was found between the Erzgebirge and the Frankenwald $(\mathrm{A}=$ $0.424 ; p<0.001)$. The results also showed low significant dissimilarities in environmental variables of the Frankenwald compared to the Fichtelgebirge $(\mathrm{A}=$ $0.211 ; p<0.001)$ and with the Thüringer Wald $(\mathrm{A}=$ $0.258 ; p<0.001)$. All other A-values were lower than the threshold of 0.2 , or not significant.

According to the variety of environmental conditions, the 222 springs accommodated a total of 284 plant species, with an average of 28 species per spring (minimum 6, maximum 55; cf. Tab. 3). Based on the 110 species used for the analyses, MRPP results showed subtle but significant differences between the five regions. All A-values were relatively low (see Tab. 6 ), the highest dissimilarity was found between the Thüringer Wald and Erzgebirge $(\mathrm{A}=0.115 ; p<0.001)$.

In the canonical analysis an automatic forwardselection of significant environmental constraints on plant species composition first was carried out on the three environmental variable subsets. From the 13 variables of the hydrochemistry subset, six variables, $\mathrm{Al}$, $\mathrm{Ca}, \mathrm{Mg}, \mathrm{PO}_{4}, \mathrm{Mn}$ and $\mathrm{K}$ were selected. These explain $59.3 \%$ of the total variation in the vegetation dataset. $3.6 \%$ total variation remained unexplained by hydrochemistry. All variables in the other subsets, hydrophysics and space, were selected as significant explanatory variables. Hydrophysical variables (discharge and electrical conductivity) explained 14.0\%, and spatial variables (longitude, latitude and altitude) explained $48.0 \%$ of the total variance.

The pCCA revealed that hydrochemical variables were the most important for species composition determination (Fig. 2). 13.9\% of total variance could be explained by the hydrochemical variables, $6.5 \%$ by these alone. The spatial and hydrophysical variables were less relevant, explaining only $3.6 \%$ and $0.8 \%$, respectively. $7.9 \%$ of the total variance was accounted for by the different combinations of environmental categories. Together the three categories (spatial, hydrophysical and hydrochemical) explain $18.8 \%$ of the total variance, $81.2 \%$ remain unexplained. In conclusion, the results from the MRPP, as well as those from the pCCA, suggest that hydrochemical variables are the most important driving factors on the species composition of springs in the five investigated areas.

When revealing the driving factors of species composition as a whole (using a CCA with the forwardselected variables from each subset), a gradient of nutrient availability and altitude was found to be the most effective factor (Fig. 3a). The first CCA axis is most affected (positively) by $\mathrm{Ca}$ and $\mathrm{Mg}$ concentrations, together with high electrical conductivity. These indicate circumneutral waters (cf. Tab. 4, Fig. 7). 
Tab. 3. Characteristics of the 222 springs. In addition to the analysed spatial $(n=3)$, hydrophysical $(n=2)$ and hydrochemical variables $(n=13)$, the size of the seepage area, water temperature, and number of species are included. Values $<$ LOQ are considered as $0.5 \times$ LOQ.

\begin{tabular}{|c|c|c|c|c|c|c|c|}
\hline region & & $\begin{array}{l}\text { Thüringer } \\
\text { Wald }\end{array}$ & $\begin{array}{c}\text { Thüringer } \\
\text { Schiefergebirge }\end{array}$ & $\begin{array}{l}\text { Franken- } \\
\text { wald }\end{array}$ & $\begin{array}{l}\text { Fichtel- } \\
\text { gebirge }\end{array}$ & $\begin{array}{l}\text { Erz- } \\
\text { gebirge }\end{array}$ & $\begin{array}{l}\text { all five } \\
\text { regions }\end{array}$ \\
\hline \multirow[t]{2}{*}{ no. of sites } & & 41 & 47 & 44 & 41 & 49 & 222 \\
\hline & unit & $\begin{array}{l}\operatorname{mean} \pm \mathrm{sd} \\
\min / \max \end{array}$ & $\begin{array}{l}\operatorname{mean} \pm \mathrm{sd} \\
\min / \max \end{array}$ & $\begin{array}{l}\text { mean } \pm \mathrm{sd} \\
\min / \max \end{array}$ & $\begin{array}{l}\operatorname{mean} \pm \mathrm{sd} \\
\min / \max \end{array}$ & $\begin{array}{l}\operatorname{mean} \pm \mathrm{sd} \\
\min / \max \end{array}$ & $\begin{array}{l}\operatorname{mean} \pm \mathrm{sd} \\
\min / \max \end{array}$ \\
\hline \multicolumn{8}{|c|}{ spatial variables } \\
\hline longitude & {$\left[{ }^{\circ}\right]$} & $10.6 / 11.0$ & $10.8 / 11.4$ & $11.2 / 11.7$ & $11.7 / 12.2$ & $12.5 / 12.8$ & $10.6 / 12.8$ \\
\hline latitude & {$\left[{ }^{\circ}\right]$} & $50.5 / 50.8$ & $50.3 / 50.7$ & $50.1 / 50.6$ & $49.9 / 50.2$ & $50.3 / 50.5$ & $49.9 / 50.8$ \\
\hline \multirow[t]{2}{*}{ altitude a.s.l. } & {$[\mathrm{m}]$} & $712 \pm 80$ & $609 \pm 122$ & $564 \pm 83$ & $712 \pm 107$ & $796 \pm 82$ & $679 \pm 127$ \\
\hline & & $535 / 830$ & $270 / 810$ & $410 / 730$ & $500 / 910$ & $625 / 925$ & $270 / 925$ \\
\hline \multicolumn{8}{|c|}{ hydrophysical variables } \\
\hline \multirow{2}{*}{\multicolumn{2}{|c|}{ discharge $\quad\left[\mathrm{L} \mathrm{s}^{-1}\right]$}} & $0.20 \pm 0.19$ & $0.06 \pm 0.10$ & $0.09 \pm 0.13$ & $0.16 \pm 0.22$ & $0.34 \pm 0.26$ & $0.17 \pm 0.22$ \\
\hline & & $0.02 / 1.00$ & $0.01 / 0.50$ & $0.02 / 0.50$ & $0.02 / 1.00$ & $0.05 / 1.00$ & $0.01 / 1.00$ \\
\hline \multirow{2}{*}{$\begin{array}{l}\text { electrical } \\
\text { conductivity }\end{array}$} & {$\left[\mu \mathrm{S} \mathrm{cm}^{-1}\right]$} & $124.1 \pm 76.9$ & $133.5 \pm 77.9$ & $136.9 \pm 109.0$ & $73.3 \pm 46.8$ & $90.7 \pm 26.2$ & $111.9 \pm 76.3$ \\
\hline & & $44.3 / 442.9$ & $33.5 / 387.0$ & $57.0 / 719.0$ & $27.0 / 223.0$ & $38.4 / 184.7$ & $27.0 / 719.0$ \\
\hline \multicolumn{8}{|c|}{ hydrochemical variables } \\
\hline \multirow[t]{2}{*}{$\mathrm{pH}$} & & $6.20 \pm 0.61$ & $5.85 \pm 0.80$ & $6.33 \pm 0.87$ & $5.54 \pm 0.56$ & $4.85 \pm 0.29$ & $5.73 \pm 0.85$ \\
\hline & & $5.04 / 7.23$ & $4.50 / 7.80$ & $4.65 / 7.50$ & $3.76 / 6.69$ & $4.44 / 5.53$ & $3.76 / 7.80$ \\
\hline \multirow[t]{2}{*}{ ANC } & {$\left[\mathrm{mmol} \mathrm{L}^{-1}\right]$} & $0.312 \pm 0.274$ & $0.301 \pm 0.458$ & $0.428 \pm 0.482$ & $0.132 \pm 0.093$ & $0.107 \pm 0.047$ & $0.254 \pm 0.345$ \\
\hline & & $0.050 / 1.270$ & $0.040 / 2.150$ & $0.035 / 1.980$ & $0.000 / 0.530$ & $0.040 / 0.230$ & $0.000 / 2.150$ \\
\hline \multirow[t]{2}{*}{$\mathrm{NH}_{4}$} & {$\left[\mathrm{mg} \mathrm{L}^{-1}\right]$} & $0.028 \pm 0.013$ & $0.018 \pm 0.014$ & $0.020 \pm 0.021$ & $0.026 \pm 0.043$ & $0.025 \pm 0.000$ & $0.023 \pm 0.023$ \\
\hline & & $0.025 / 0.095$ & $0.004 / 0.072$ & $0.013 / 0.127$ & $0.013 / 0.240$ & $0.025 / 0.025$ & $0.004 / 0.240$ \\
\hline \multirow[t]{2}{*}{$\mathrm{NO}_{3}$} & {$\left[\mathrm{mg} \mathrm{L}^{-1}\right]$} & $7.03 \pm 2.41$ & $5.70 \pm 6.10$ & $6.92 \pm 7.80$ & $4.17 \pm 2.66$ & $5.69 \pm 2.03$ & $5.90 \pm 4.88$ \\
\hline & & $2.86 / 12.00$ & $0.35 / 36.49$ & $0.37 / 45.90$ & $0.17 / 10.00$ & $2.08 / 11.00$ & $0.17 / 45.90$ \\
\hline \multirow[t]{2}{*}{$\mathrm{SO}_{4}$} & {$\left[\mathrm{mg} \mathrm{L}^{-1}\right]$} & $21.63 \pm 6.43$ & $26.42 \pm 16.44$ & $21.50 \pm 6.47$ & $18.95 \pm 19.16$ & $28.64 \pm 8.79$ & $23.67 \pm 12.96$ \\
\hline & & $5.84 / 36.60$ & $6.05 / 88.46$ & $11.40 / 43.70$ & $2.57 / 92.50$ & $5.13 / 48.00$ & $2.57 / 92.50$ \\
\hline \multirow[t]{2}{*}{$\mathrm{PO}_{4}$} & {$\left[\mathrm{mg} \mathrm{L}^{-1}\right]$} & $0.195 \pm 0.150$ & $0.039 \pm 0.061$ & $0.140 \pm 0.000$ & $0.140 \pm 0.000$ & $0.149 \pm 0.090$ & $0.131 \pm 0.096$ \\
\hline & & $0.125 / 0.590$ & $0.003 / 0.408$ & $0.140 / 0.140$ & $0.140 / 0.140$ & $0.125 / 0.634$ & $0.003 / 0.634$ \\
\hline \multirow[t]{2}{*}{$\mathrm{Ca}$} & {$\left[\mathrm{mg} \mathrm{L}^{-1}\right]$} & $11.99 \pm 5.84$ & $8.53 \pm 9.12$ & $11.20 \pm 9.02$ & $5.11 \pm 5.13$ & $7.16 \pm 3.06$ & $8.76 \pm 7.23$ \\
\hline & & $4.44 / 26.20$ & $0.40 / 55.80$ & $2.50 / 44.80$ & $1.11 / 25.90$ & $2.04 / 15.80$ & $0.40 / 55.80$ \\
\hline \multirow[t]{2}{*}{$\mathrm{Mg}$} & {$\left[\mathrm{mg} \mathrm{L}^{-1}\right]$} & $1.97 \pm 0.94$ & $2.68 \pm 1.61$ & $4.44 \pm 2.23$ & $1.90 \pm 1.60$ & $1.68 \pm 0.71$ & $2.53 \pm 1.81$ \\
\hline & & $0.41 / 6.22$ & $0.50 / 8.00$ & $1.69 / 12.30$ & $0.28 / 6.80$ & $0.75 / 3.87$ & $0.28 / 12.30$ \\
\hline \multirow[t]{2}{*}{ K } & {$\left[\mathrm{mg} \mathrm{L}^{-1}\right]$} & $3.078 \pm 2.101$ & $0.651 \pm 0.486$ & $0.954 \pm 0.388$ & $1.215 \pm 0.650$ & $1.308 \pm 0.429$ & $1.409 \pm 1.298$ \\
\hline & & $0.125 / 10.500$ & $0.140 / 2.570$ & $0.297 / 1.910$ & $0.386 / 3.230$ & $0.560 / 2.130$ & $0.125 / 10.500$ \\
\hline \multirow[t]{2}{*}{$\mathrm{Mn}$} & {$\left[\mu \mathrm{g} \mathrm{L}^{-1}\right]$} & $11.27 \pm 8.12$ & $29.66 \pm 46.00$ & $68.88 \pm 174.62$ & $43.18 \pm 61.06$ & $131.80 \pm 122.65$ & $59.08 \pm 110.34$ \\
\hline & & $10.00 / 62.00$ & $0.10 / 214.00$ & $0.25 / 900.00$ & $0.25 / 230.00$ & $10.00 / 560.00$ & $0.10 / 900.00$ \\
\hline \multirow[t]{2}{*}{$\mathrm{Al}$} & {$\left[\mu \mathrm{g} \mathrm{L}^{-1}\right]$} & $31.3 \pm 51.4$ & $257.7 \pm 493.7$ & $116.0 \pm 231.6$ & $338.8 \pm 544.7$ & $1042.1 \pm 917.3$ & $375.9 \pm 659.7$ \\
\hline & & $4.0 / 332.0$ & $2.1 / 1914.0$ & 1.4 / 843.0 & $2.7 / 2080.0$ & $100.0 / 4050.0$ & $1.4 / 4050.0$ \\
\hline \multirow[t]{2}{*}{$\mathrm{Cd}$} & {$\left[\mu \mathrm{g} \mathrm{L}^{-1}\right]$} & $0.100 \pm 0.167$ & $0.097 \pm 0.122$ & $0.150 \pm 0.245$ & $0.206 \pm 0.213$ & $0.504 \pm 0.250$ & $0.218 \pm 0.258$ \\
\hline & & $0.050 / 1.100$ & $0.005 / 0.540$ & $0.050 / 1.620$ & $0.050 / 1.140$ & $0.050 / 1.280$ & $0.005 / 1.620$ \\
\hline \multirow[t]{2}{*}{$\mathrm{Na}$} & {$\left[\mathrm{mg} \mathrm{L}^{-1}\right]$} & $5.58 \pm 8.39$ & $3.12 \pm 3.45$ & $7.56 \pm 13.33$ & $4.20 \pm 3.49$ & $3.44 \pm 2.44$ & $4.73 \pm 7.48$ \\
\hline & & $1.04 / 37.50$ & $0.30 / 17.80$ & $1.37 / 80.70$ & $1.66 / 14.40$ & $1.42 / 18.80$ & $0.30 / 80.70$ \\
\hline \multicolumn{8}{|c|}{ further variables (not included in analyses) } \\
\hline \multirow[t]{2}{*}{ seepage area } & {$\left[\mathrm{m}^{2}\right]$} & $25 \pm 17$ & $45 \pm 40$ & $94 \pm 96$ & $52 \pm 81$ & $18 \pm 8$ & $46 \pm 64$ \\
\hline & & $6 / 90$ & $8 / 200$ & $7 / 489$ & $1 / 387$ & $6 / 48$ & $1 / 489$ \\
\hline water temp. & {$\left[{ }^{\circ} \mathrm{C}\right]$} & $7.4 \pm 1.3$ & n.a. & $6.8 \pm 1.4$ & $5.6 \pm 1.5$ & $6.7 \pm 0.7$ & $(6.6 \pm 1.4)$ \\
\hline & & $5.6 / 11.3$ & n.a. & $3.6 / 9.0$ & $1.0 / 8.6$ & $5.5 / 9.2$ & $(1.0 / 11.3)$ \\
\hline no. of species & & $29 \pm 7$ & $28 \pm 11$ & $37 \pm 10$ & $25 \pm 11$ & $23 \pm 6$ & $28 \pm 10$ \\
\hline & & $17 / 44$ & $6 / 51$ & $10 / 54$ & $11 / 55$ & $15 / 38$ & $6 / 55$ \\
\hline
\end{tabular}




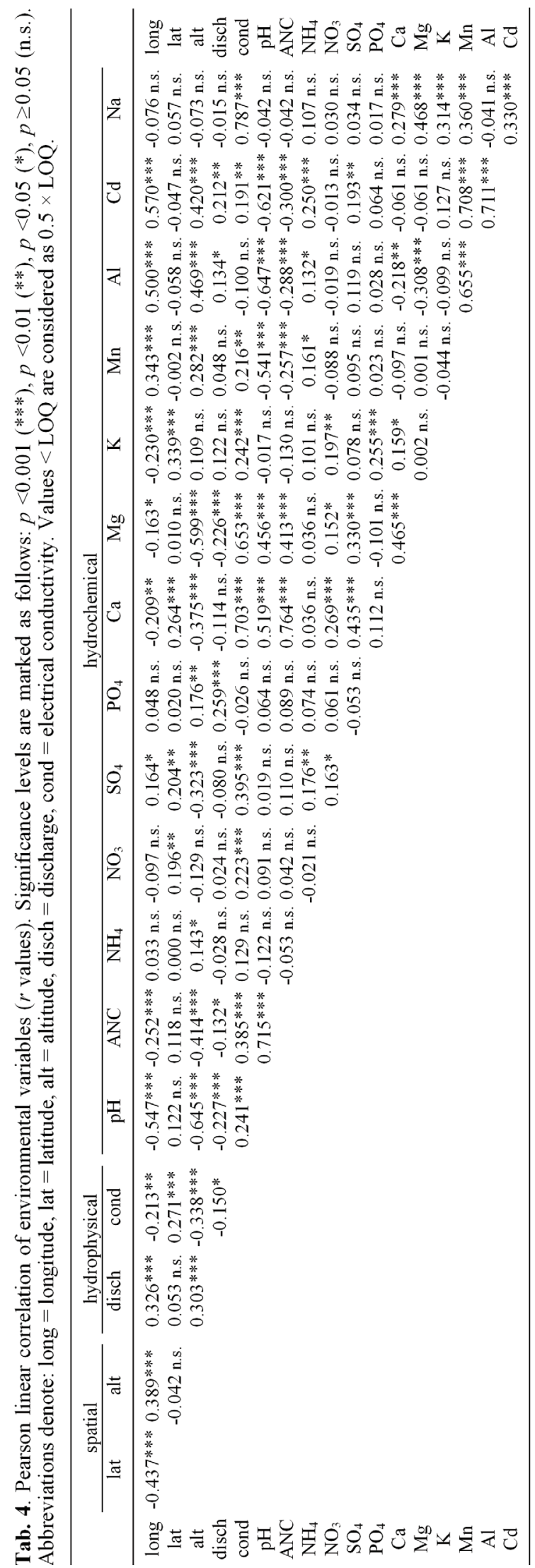


Tab. 5. Comparison of the five regions, calculated by a multiple response permutation procedure (MRPP; Euclidean dissimilarity; 999 permutations) based on 9 of the 11 forward-selected environmental variables. Latitude and longitude were excluded from this analysis to avoid a spatial bias in the regional comparison. The resulting A-values denote a chance-corrected estimate of the proportion of the distances explained by regional identity. The combined analysis of all five regions resulted in $\mathrm{A}=0.253, p<0.001$. Significance levels for the pair-wise comparisons are Bonferroni-corrected and marked as follows: $p<0.001$ (***) $^{*} p<0.01(* *), p<0.05$ (*), $p \geq 0.05$ (n.s.).

\begin{tabular}{lcccc}
\hline region & $\begin{array}{c}\text { Thüringer } \\
\text { Wald } \\
\text { A }\end{array}$ & $\begin{array}{c}\text { Thüringer } \\
\text { Schiefergebirge } \\
\text { A }\end{array}$ & $\begin{array}{c}\text { Franken- } \\
\text { wald } \\
\text { A }\end{array}$ & $\begin{array}{c}\text { Fichtel- } \\
\text { gebirge } \\
\text { A }\end{array}$ \\
\hline Erzgebirge & $0.108 * * *$ & $0.265 * * *$ & $0.424 * * *$ & $0.087 * * *$ \\
Fichtelgebirge & 0.000 n.s. & $0.077 * * *$ & $0.211^{* * *}$ & \\
Frankenwald & $0.258^{* * *}$ & $0.028 *$ & & \\
Thüringer Schiefergebirge & $0.101 * * *$ & & & \\
\hline
\end{tabular}

Tab. 6. Comparison of the five regions, calculated by a multiple response permutation procedure (MRPP; Euclidean dissimilarity; 999 permutations) based on the 110 plant species. The resulting A-values denote a chance-corrected estimate of the proportion of the distances explained by regional identity. The combined analysis of all five regions resulted in $\mathrm{A}=0.081, p<0.001$. Significance levels for the pair-wise comparisons are Bonferroni-corrected and marked as follows: $p<0.001(* * *), p<0.01(* *), p<0.05\left(^{*}\right), p$ $\geq 0.05$ (n.s.).

\begin{tabular}{lcccc}
\hline region & $\begin{array}{c}\text { Thüringer } \\
\text { Wald } \\
\text { A }\end{array}$ & $\begin{array}{c}\text { Thüringer } \\
\text { Schiefergebirge } \\
\text { A }\end{array}$ & $\begin{array}{c}\text { Franken- } \\
\text { wald } \\
\text { A }\end{array}$ & $\begin{array}{c}\text { Fichtel- } \\
\text { gebirge } \\
\text { A }\end{array}$ \\
\hline Erzgebirge & $0.115 * * *$ & $0.057 * * *$ & $0.087 * * *$ & $0.034 * * *$ \\
Fichtelgebirge & $0.077 * * *$ & $0.024 * * *$ & $0.032 * * *$ & \\
Frankenwald & $0.051 * * *$ & $0.023 * * *$ & & \\
Thüringer Schiefergebirge & $0.035 * * *$ & & & \\
\hline
\end{tabular}

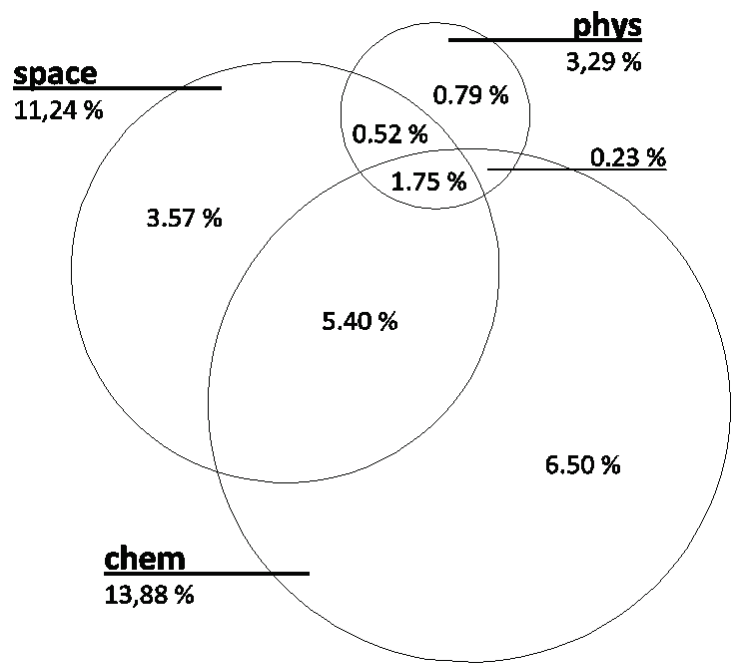

Fig. 2. Proportion of total variance explained by the forward-selected environmental variables of the subsets, space ( $\mathrm{n}=3 \mathrm{spatial}$ variables), phys $(\mathrm{n}=2$ hydrophysical variables) and chem ( $\mathrm{n}=6$ hydrochemical variables), calculated by partial canonical correspondence analysis (pCCA). Together $18.76 \%$ of the total variance is explained. The size of circles and segments is approximate. 

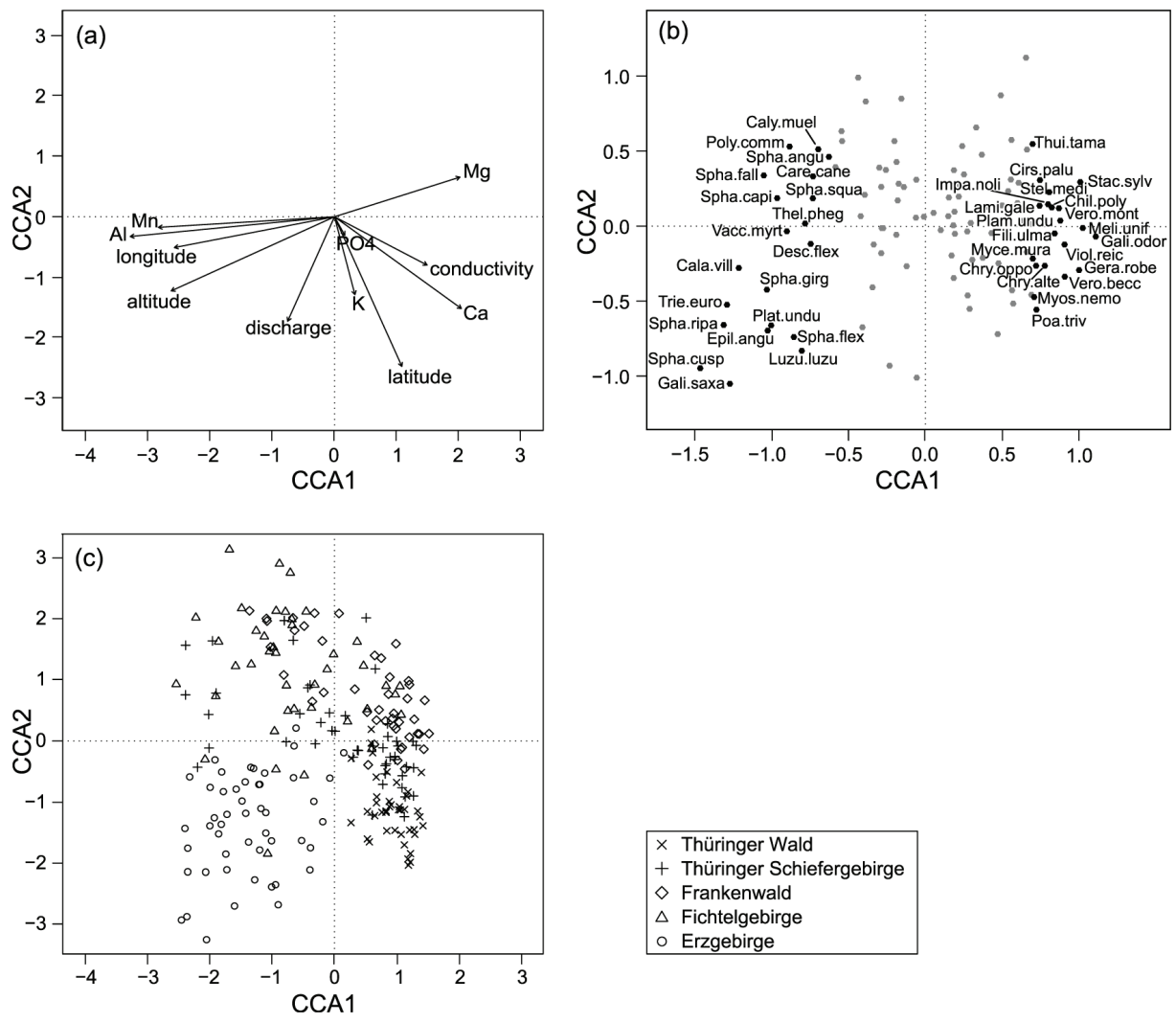

Fig. 3. Ordination diagrams for the canonical correspondence analysis (CCA; 199 permutations, $p<0.005)$ after forward-selection of the environmental variables, showing (a) three spatial, two hydrophysical and six hydrochemical variables, (b) 110 species (only species ranked within the lowest 20 and highest 20 CCA first axis scores are labelled, cf. Tab. 7), and (c) 222 sites. $18.76 \%$ of total variance is explained by the 11 selected environmental variables.

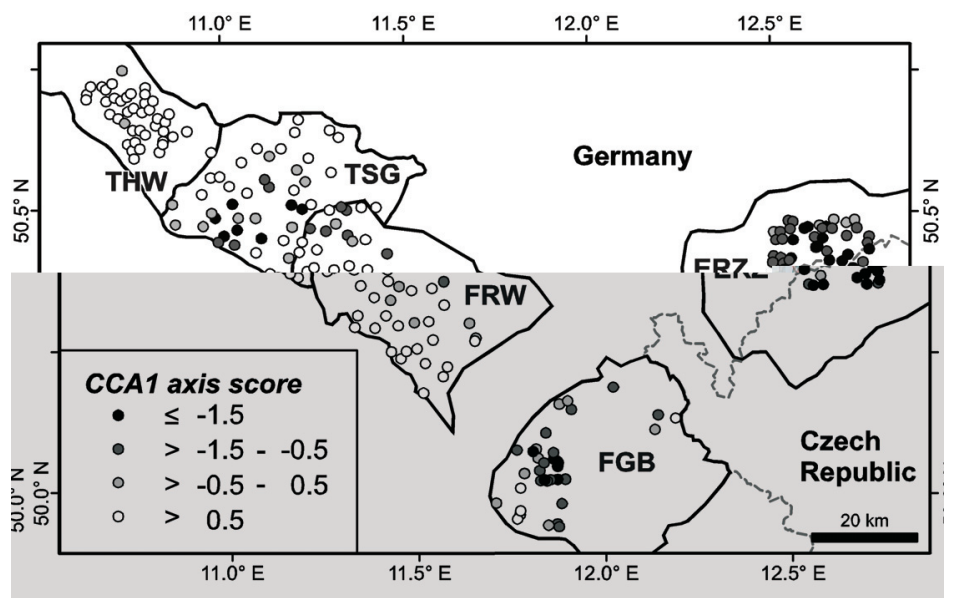

Fig. 4. Map of CCA first axis scores of the 222 sites. Abbreviations denote the five regions: $\mathrm{THW}=\mathrm{Thüringer}$ Wald, TSG $=$ Thüringer Schiefergebirge, FRW = Frankenwald, FGB = Fichtelgebirge and ERZ = Erzgebirge.

In the opposite direction, high $\mathrm{Al}$ and $\mathrm{Mn}$ concentrations load the first CCA axis negatively. This end of the main gradient is related to higher altitude and longitude, and can be linked to acidic waters (cf. Tab. 4, Fig. 7). The latter are characterised by the occurrence of peat-building mosses (Polytrichum commune, several species of Sphagnum) and clonal grasses (Calamagrostis villosa, Deschampsia flexuosa). Under neutral,
$\mathrm{Ca}$ - and $\mathrm{Mg}$-rich conditions, herbaceous species predominate (Fig. 3b, Tab. 7).

With respect to the sites, the main CCA gradient is also reflected by the five regions (Figs $3 \mathrm{c}$ and 4 , Tab. 8). Whereas positive CCA first axis scores identify circumneutral conditions throughout the Thüringer Wald, Al- and Mn-rich conditions prevail in the Erzgebirge, indicated by the lowest mean CCA first axis scores. In 
Tab. 7. CCA axis scores for those species ranked within the lowest 20 and highest 20 CCA first axis scores. Their frequency and occurrence in total (222 sites), and in the five regions are also given (absent: ., present: + , present with a frequency $>50 \%$ : ++ ). Abbreviations for the regions: THW $=$ Thüringer Wald, TSG $=$ Thüringer Schiefergebirge, FRW = Frankenwald, FGB = Fichtelgebirge and ERZ = Erzgebirge.

\begin{tabular}{|c|c|c|c|c|c|c|c|c|c|}
\hline Species & CCA 1 & CCA 2 & $\begin{array}{c}\text { Freq. } \\
\text { sites }\end{array}$ & $\begin{array}{l}\text { Freq. } \\
\text { regions }\end{array}$ & THW & TSG & FRW & FGB & ERZ \\
\hline Sphagnum cuspidatum & -1.498 & -0.944 & 10 & 2 & . & . & + & . & + \\
\hline Sphagnum riparium & -1.342 & -0.656 & 36 & 3 & . & . & + & + & + \\
\hline Trientalis europaea & -1.319 & -0.521 & 31 & 4 & + & + & . & + & + \\
\hline Galium saxatile & -1.300 & -1.048 & 44 & 4 & + & + & + & . & ++ \\
\hline Calamagrostis villosa & -1.241 & -0.276 & 93 & 4 & + & + & . & ++ & ++ \\
\hline Sphagnum fallax & -1.074 & 0.341 & 65 & 4 & . & + & + & + & + \\
\hline Sphagnum girgensohnii & -1.053 & -0.420 & 53 & 5 & + & + & + & + & ++ \\
\hline Epilobium angustifolium & -1.048 & -0.693 & 32 & 4 & . & + & + & + & + \\
\hline Plagiothecium undulatum & -1.025 & -0.658 & 60 & 5 & + & + & + & + & ++ \\
\hline Sphagnum capillifolium & -0.985 & 0.189 & 12 & 4 & . & + & + & + & + \\
\hline Vaccinium myrtillus & -0.920 & -0.031 & 87 & 4 & . & + & + & ++ & ++ \\
\hline Polytrichum commune & -0.902 & 0.533 & 90 & 5 & + & ++ & + & ++ & ++ \\
\hline Sphagnum flexuosum & -0.874 & -0.736 & 10 & 3 & + & . & + & . & + \\
\hline Luzula luzuloides & -0.820 & -0.828 & 12 & 3 & + & + & . & . & + \\
\hline Thelypteris phegopteris & -0.798 & 0.020 & 49 & 5 & + & + & + & + & + \\
\hline Deschampsia flexuosa & -0.761 & -0.115 & 82 & 5 & + & + & + & ++ & ++ \\
\hline Sphagnum squarrosum & -0.747 & 0.188 & 68 & 5 & + & + & + & + & + \\
\hline Carex canescens & -0.745 & 0.334 & 31 & 5 & + & + & + & + & + \\
\hline Calypogeia muelleriana & -0.711 & 0.515 & 64 & 5 & + & + & + & ++ & + \\
\hline Sphagnum angustifolium & -0.640 & 0.465 & 17 & 4 & + & . & + & + & + \\
\hline Thuidium tamariscinum & 0.719 & 0.550 & 21 & 4 & + & + & + & + & . \\
\hline Mycelis muralis & 0.720 & -0.214 & 15 & 4 & + & + & + & + & . \\
\hline Myosotis nemorosa & 0.730 & -0.470 & 46 & 4 & ++ & + & + & + & . \\
\hline Chrysosplenium oppositifolium & 0.742 & -0.261 & 118 & 5 & ++ & ++ & ++ & + & + \\
\hline Poa trivialis & 0.745 & -0.554 & 50 & 3 & ++ & + & . & . & + \\
\hline Lamium galeobdolon & 0.765 & 0.139 & 31 & 4 & + & + & + & + & . \\
\hline Cirsium palustre & 0.768 & 0.310 & 21 & 4 & + & + & + & + & . \\
\hline Chrysosplenium alternifolium & 0.800 & -0.261 & 63 & 5 & ++ & + & + & + & + \\
\hline Impatiens noli-tangere & 0.822 & 0.148 & 70 & 5 & + & + & ++ & + & + \\
\hline Stellaria media & 0.830 & 0.230 & 11 & 2 & . & . & + & + & . \\
\hline Chiloscyphus polyanthos & 0.847 & 0.127 & 42 & 4 & + & + & + & + & . \\
\hline Filipendula ulmaria & 0.867 & -0.046 & 19 & 4 & + & + & + & + & . \\
\hline Veronica montana & 0.895 & 0.122 & 33 & 4 & + & + & + & + & . \\
\hline Plagiomnium undulatum & 0.904 & 0.039 & 76 & 4 & ++ & + & ++ & + & . \\
\hline Viola reichenbachiana & 0.933 & -0.119 & 12 & 3 & + & . & + & + & . \\
\hline Veronica beccabunga & 0.934 & -0.334 & 10 & 3 & + & + & + & . & . \\
\hline Geranium robertianum & 1.029 & -0.290 & 24 & 4 & + & + & + & + & . \\
\hline Stachys sylvatica & 1.037 & 0.297 & 17 & 3 & . & + & + & + & . \\
\hline Melica uniflora & 1.054 & -0.010 & 12 & 3 & + & + & + & . & . \\
\hline Galium odoratum & 1.141 & -0.067 & 11 & 2 & + & . & + & . & . \\
\hline
\end{tabular}

Tab. 8. CCA axis scores for the 222 sites, given as mean values and ranges for the five regions and for all investigated springs.

\begin{tabular}{|c|c|c|c|c|c|c|}
\hline region & $\begin{array}{l}\text { Thüringer } \\
\text { Wald } \\
\text { mean } \pm \text { sd } \\
\text { min / max }\end{array}$ & $\begin{array}{c}\text { Thüringer } \\
\text { Schiefergebirge } \\
\text { mean } \pm \text { sd } \\
\min / \max \end{array}$ & $\begin{array}{l}\text { Franken- } \\
\text { wald } \\
\text { mean } \pm \text { sd } \\
\text { min / max }\end{array}$ & $\begin{array}{l}\text { Fichtel- } \\
\text { gebirge } \\
\text { mean } \pm \text { sd } \\
\min / \max \end{array}$ & $\begin{array}{c}\text { Erz- } \\
\text { gebirge } \\
\text { mean } \pm \text { sd } \\
\min / \max \end{array}$ & $\begin{array}{l}\text { all five } \\
\text { regions } \\
\text { mean } \pm \text { sd } \\
\min / \max \end{array}$ \\
\hline CCA1 & $\begin{array}{c}0.936 \pm 0.305 \\
0.267 / 1.426\end{array}$ & $\begin{array}{l}0.124 \pm 1.123 \\
-2.399 / 1.316\end{array}$ & $\begin{array}{l}0.514 \pm 0.821 \\
-1.368 / 1.524\end{array}$ & $\begin{array}{l}-0.673 \pm 0.916 \\
-2.549 / 1.076\end{array}$ & $\begin{array}{l}-1.375 \pm 0.671 \\
-2.463 / 0.150\end{array}$ & $\begin{array}{l}-0.127 \pm 1.169 \\
-2.549 / 1.524\end{array}$ \\
\hline CCA2 & $\begin{array}{l}-1.140 \pm 0.513 \\
-2.044 / 0.190\end{array}$ & $\begin{array}{l}0.110 \pm 0.784 \\
-1.247 / 2.023\end{array}$ & $\begin{array}{l}0.783 \pm 0.779 \\
-0.459 / 2.140\end{array}$ & $\begin{array}{l}1.136 \pm 1.001 \\
-1.856 / 3.146\end{array}$ & $\begin{array}{l}-1.375 \pm 0.824 \\
-3.268 / 0.211\end{array}$ & $\begin{array}{l}-0.126 \pm 1.277 \\
-3.268 / 3.146\end{array}$ \\
\hline
\end{tabular}

the three central regions, the Thüringer Schiefergebirge, the Frankenwald and the Fichtelgebirge, a wider range of CCA first axis scores was encountered (Fig. 4). There, Al- and Mn-dominated spring waters are mainly confined to the highest altitudes, coinciding with low pH (Fig. 5).

As the correlations between the individual environmental variables (Tab. 4) showed that the main variance in our dataset follows an altitudinal and/or acidity gradient, we correlated several hydrological variables with these two factors. Both $\mathrm{pH}$ and electrical conductivity decreased linearly with altitude (best Pearson correlation; Fig. 6). However, the acidity gradients of $\mathrm{ANC}, \mathrm{Ca}$ and $\mathrm{Mg}$ are best characterised by exponential correlations (Fig. 7). 


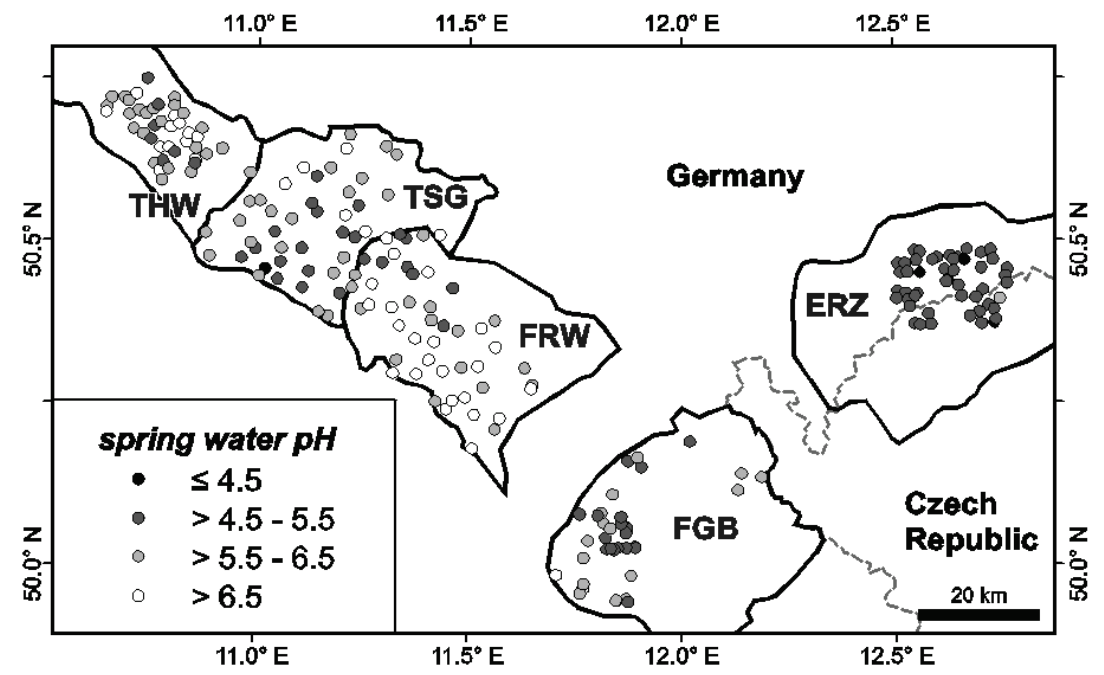

Fig. 5. Map of crenic water $\mathrm{pH}$-values of the 222 sites. Abbreviations denote the five regions: $\mathrm{THW}=\mathrm{Thüringer}$ Wald, $\mathrm{TSG}=$ Thüringer Schiefergebirge, FRW = Frankenwald, FGB = Fichtelgebirge and ERZ = Erzgebirge.
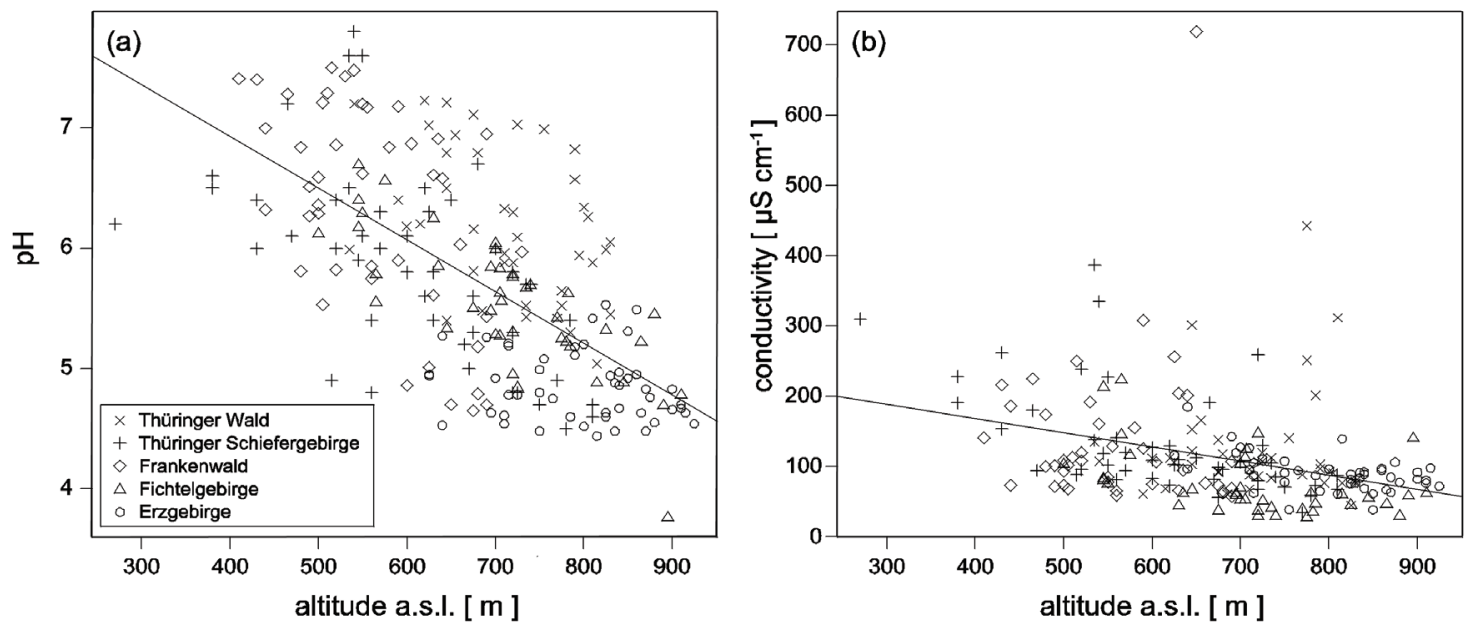

Fig. 6. Altitudinal gradients of $\mathrm{pH}$ and electrical conductivity, fitted by a Pearson linear correlation. (a) $\mathrm{pH}-\mathrm{value}\left(r^{2}=0.416, p\right.$ $<0.001)$, and (b) electrical conductivity $\left(r^{2}=0.114, p<0.001\right)$.

\section{DISCUSSION}

\subsection{Crenic water characteristics and spatial relationships}

The five investigated regions showed low, but remarkable differences in the properties of their crenic waters (Tabs 3 and 5), in particular with respect to the hydrochemical variables, and to a lesser extent to their hydrophysical variables. Although the main characteristics were shared, i.e. connatural - siliceous bedrock, near-surface aquifer, helocrenic springs, forested catchments, and climatic traits - spatial patterns were found in the hydrochemical characteristics, with an overall longitudinal gradient (Tab. 4, Fig. 5).

Acidity increased from West to East, marked most prominently by a significant decline in $\mathrm{pH}$ and ANC.
Our data suggested that this is an altitudinal effect (Fig. 6), which is also significantly related to longitude (Tab. 4): the eastern regions of the Fichtelgebirge and Erzgebirge are higher. Low $\mathrm{pH}$ is linked to higher altitudes by natural (colder and wetter climate, genesis of podsolic soils, higher proportion of coniferous trees), and anthropogenic (acidic depositions, forestry), processes in the forested catchments (cf. Strohbach et al. 2009). Lithology plays a minor role in the altitudinal gradient, and was seen for each of the five regions (Fig. 6a). However, the geochemical characteristics of the regions could also contribute to the longitudinal acidity gradient. In spite of the fact that all the bedrock is siliceous, buffering capacities differ between the types of rock (cf. Tab. 1) and soils, and therefore between the regions. 

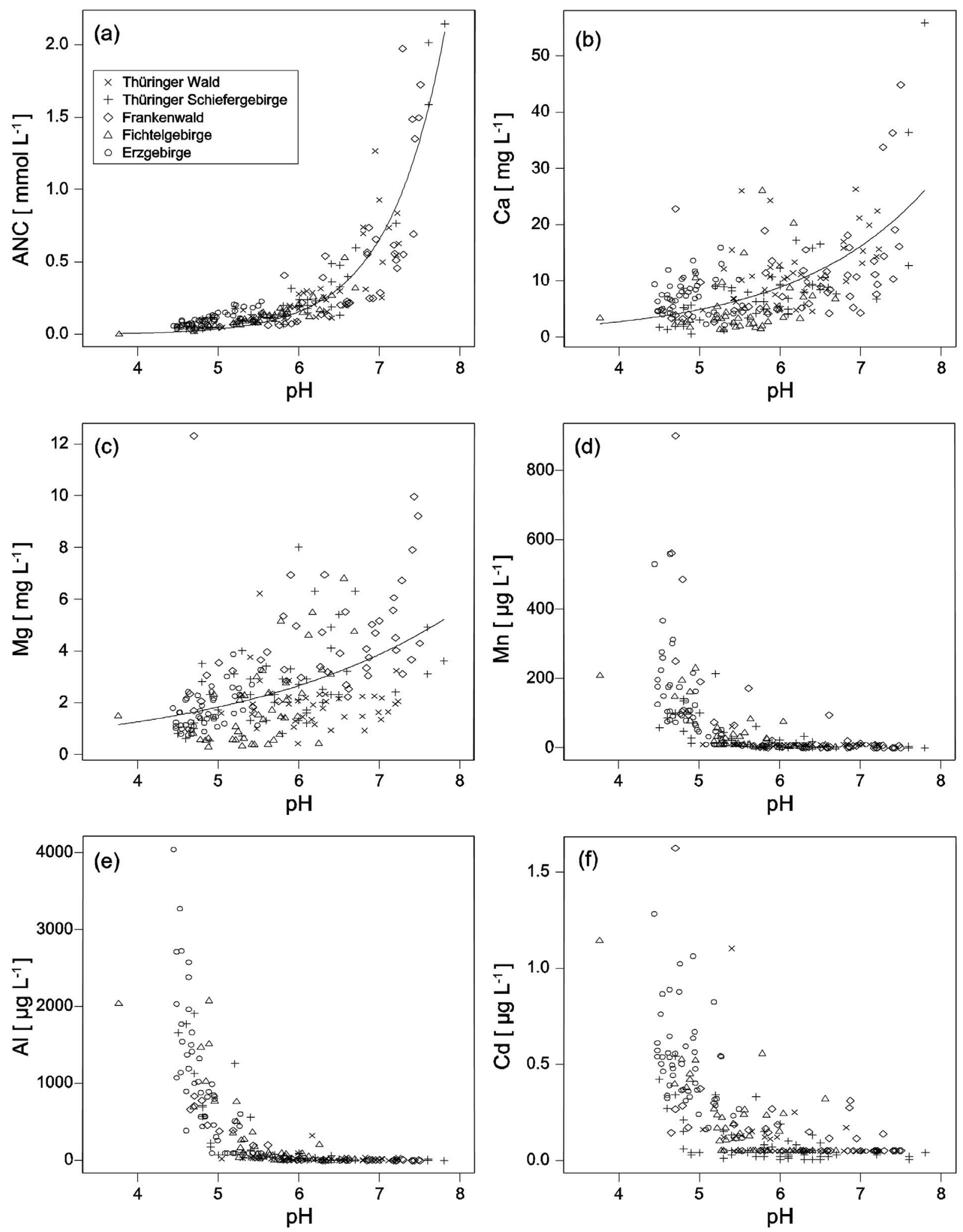

Fig. 7. $\mathrm{pH}$ gradients of selected hydrochemical variables, fitted by an exponential regression. Values $<$ LOQ are considered as $0.5 \times$ LOQ. (a) Acid neutralising capacity $\left(r^{2}=0.807, p<0.0001\right)$, (b) Calcium $\left(r^{2}=0.354, p<0.0001\right)$, (c) Magnesium $\left(\mathrm{r}^{2}=217, p\right.$ $<0.0001$ ), (d) Manganese (n.s.), (e) Aluminium (n.s.), and (f) Cadmium (n.s.). 
This has also been discussed for other regions (Probst et al. 1999; Williard et al. 2005). Thus, it is not possible to be conclusive about the stressors in the catchments, when only crenic waters are considered. Other catchment characteristics that influence acidifying processes, such as bedrock, climatic parameters, and forest vegetation, must be included in the analyses. However, Strohbach et al. (2009) showed the close connection of crenic waters to catchment characterisitics, especially those related to acidifying processes.

Within each of the five regions there were differences between the individual springs with respect to the acidity gradient. The springs in the Thüringer Wald (all pH-values above 5.00) and in the Erzgebirge (all $\mathrm{pH}$-values below 5.55) covered narrower ranges of acidity. In contrast, the variability within a single region was most pronounced for the three central regions, the Thüringer Schiefergebirge, the Frankenwald and the Fichtelgebirge, where a broader range of $\mathrm{pH}$-values was encountered and highly acidic springs were linked to higher altitudes. However, slope and orientation of the catchment (Palmer et al. 2004; Rantakari et al. 2004), as well as surface roughness of the vegetation (i.e. deciduous or coniferous forest; Williard et al. 2005) can alter the deposition load of the catchment and therefore the acidity of crenic waters. Those factors were not included in this investigation, but are covered for some of our study sites by Strohbach et al. (2009). They assume that altitude acts as a sum parameter incorporating various factors that influence acidifying processes in the catchment, via bedrock, climatic parameters and forest vegetation.

In order to appraise the biogeochemical processes of acidification and recovery in springs and their catchments or, as here, just their acidity status, it is not sufficient merely to consider $\mathrm{pH}$. Measuring the acidifying compounds $\mathrm{NO}_{3}{ }^{-}$and $\mathrm{SO}_{4}{ }^{2-}$ in crenic waters is even less meaningful (cf. Tab. 4). The concentrations of elements are involved in soil and groundwater buffering systems can indicate the ability of ecosystems to counterbalance acidic deposition. Acidic crenic waters are characterised by high concentrations of $\mathrm{Al}, \mathrm{Cd}$ and Mn. Circumneutral waters, with carbonate and silicate buffering, incorporate high concentrations of $\mathrm{Ca}$ and $\mathrm{Mg}$ (Tab. 4, Fig. 7). Such hydrochemical interrelationships apply to both between-region and within-region comparisons. However, the complexity of the hydrochemistry is an argument for adopting a biomonitoring approach.

As a result of the physically dense bedrock in the studied siliceous mountain ranges, groundwater flow mainly occurs close to the surface, as so-called interflow. This is demonstrated by the abundance of springs, as well as by their chemistry and discharge performance. Crenic water quality is very closely linked to catchment status and processes and springs can therefore act as suitable indicator systems for the qualitative situation of their forested catchments in this area (Beierkuhnlein \& Durka 1993). However, quantifying export budgets would require that the catchments were precisely delimited and the amount and quality of crenic water discharge were continuously measured (e.g., Lischeid et al. 1998), which is certainly not feasible for biomonitoring at the landscape scale.

\subsection{Determining factors for crenic vegetation}

Comparing the five regions, MRPP only revealed subtle dissimilarities in species occurrence and composition. This clearly demonstrates the relatedness of the crenic vegetation at all study areas.

The hydrochemical subset of environmental variables was found principally to determine plant community composition. Spatial variables were less, and hydrophysical variables, least important. A relatively high proportion of variance in the pCCA could be explained by combinations of two or all environmental subsets. This is plausible because environmental variables from different subsets were shown to be correlated. In particular, the altitudinal dependencies of $\mathrm{pH}$ and of the concentrations of $\mathrm{Al}, \mathrm{Ca}$, and $\mathrm{Mg}$ (which are involved in buffering processes) link the spatial subset to the hydrochemical subset of environmental variables. The hydrophysical variables are comparable within and between the investigated regions, which limits their effect on species occurrence.

With respect to the hydrochemical variables, the forward-selection procedure combined with the CCA revealed that $\mathrm{Ca}, \mathrm{Mg}, \mathrm{Al}$, and $\mathrm{Mn}$ are the major representative factors that explain the species composition of springs. This can be interpreted as a gradient of nutrient availability (such as $\mathrm{Ca}$ and $\mathrm{Mg}$ ) or, vice versa, as a gradient of potentially toxic elements (such as $\mathrm{Al}$ and $\mathrm{Mn}$ ). Despite both gradients being closely related to acidity status (cf. Tab. 4, Fig. 7), we assume that acidity does not influence species occurrences directly, but affects nutrient availability and the presence of potentially toxic elements. During buffering processes $\mathrm{Al}, \mathrm{Cd}$, and $\mathrm{Mn}$ are released at $\mathrm{pH}$-values $<4.2$. $\mathrm{Mg}$ and $\mathrm{Ca}$ are mainly released at $\mathrm{pH}$-values between 6.2 and 8.6 , which indicates that species occurrence and therefore plant community composition are responding indirectly to acidity. However, $\mathrm{pH}$ can serve as powerful proxy to represent this gradient, even if it was eliminated by the forward-selection procedure. Our findings are in accordance with studies that found the vegetation composition of springs and crenic fens to be fundamentally determined by water chemistry, particularly a gradient of acidity and nutrient availability (Beierkuhnlein \& Gräsle 1998; Wheeler \& Proctor 2000; Hájek et al. 2002; Hájková et al. 2008).

Apart from this gradient, other environmental factors might also influence species composition. Besides acidity and nutrient availability, Hinterlang (1992) discusses light as major determining factor for his classi- 
fication of plant associations of springs of Central Europe. However, for forest springs, Beierkuhnlein \& Gräsle (1998) observed that light supply, which also reflects shading provided by surrounding forest stands, modulates the vegetation composition of springs, albeit to a lesser extent than acidity. Spatial factors, such as the extent of the spring habitats or the distance between them, can affect seed dispersal and therefore species occurrence and establishment in the island-like crenic habitats. However, such restrictions are less important in our study, because the helocrenic habitats were selected based on clear criteria. Spatially more extensive fens and mires were excluded from the dataset, as were point source rheocrenic springs, in which the physical conditions of the brook prevail from the start.

Restricting our study to siliceous, helocrenic springs, and sampling at the point of discharge was advantageous compared with results from various other studies in springs and fens of the northern hemisphere (Vitt \& Chee 1990; Wheeler \& Proctor 2000; Bragazza \& Gerdol 2002; Nekola 2004; Tahvanainen 2004). In these, the type of habitat was often not precisely defined or constrained. Only at spatially restricted springs, or at point discharges of groundwater is the influence of the surrounding environment negligible. Spatially extended fens are more exposed to insolation, frost and wind. As the emerging groundwater rapidly adapts to the external temperature and atmosphere by $\mathrm{CO}_{2}$ out-gassing, small scale gradients in water chemistry and physics occur. Water quality is modified when it percolates over several meters through dense vegetation. Thus, sampling errors and noise in data sets can be due to a lack of standardization of measurements. The sampling distance from the point of discharge must be accounted for.

The combination of the above mentioned topics provides an excellent framework for the biomonitoring of the biogeochemical status of forested catchments using crenic vegetation. We showed that species occurrence in the investigated regions is determined by the same hydrological factors, despite capturing a wider range of vegetation and environmental data than Strohbach et al. (2009). This suggests a potential wider application of such a monitoring system, spatially and temporally. When environmental conditions change, crenic species and their assemblages are likely to respond (Glazier 1991; Zollhöfer et al. 2000). It can be expected that changes in crenic water quality will affect the stenoecious, crenobiontic and crenophilous species first and most strongly (Ferrington 1998; Zollhöfer et al. 2000; Cantonati et al. 2006). Non-motile groups of organisms, such as plants, are especially suitable indicators of the biogeochemical conditions in springs. As the deposition of various acidifying compounds (e.g., sulphuric acid) has been drastically reduced, the regeneration of Central European forest ecosystems is a realistic prospect (Stoddard et al. 1999; Alewell et al.
2001). Future comparisons will allow the process of acidification and recovery to be followed. Our survey offers a sound basis for tackling such questions.

\section{CONCLUSIONS}

Hydrochemical factors have been found to be the fundamental drivers of plant community composition in helocrenic springs in Central European mountain ranges. Spatial factors, particularly altitude, are closely related to the hydrochemical factors, but are less important. Hydrophysical factors play a minor role. In particular, species occurrence is affected by the gradient of nutrient availability which is in return affected by acidity. This gradient is characterised by higher $\mathrm{Ca}$ and $\mathrm{Mg}$ concentrations in circumneutral waters, whereas $\mathrm{Al}, \mathrm{Cd}$, and $\mathrm{Mn}$ are found at higher concentrations in acidic waters.

In general, springs can be considered as low dynamic ecosystems, particularly if they are located in forested catchments. This allows organisms to adapt to habitat conditions over a relatively long time, and to develop a steady state in community composition. External factors such as disturbances or human landuse are negligible, which provides a good basis for the biomonitoring of the hydrochemical status of crenic waters. Spatial patterns in crenic vegetation emerge at the landscape scale, and provide valuable ecological information on crenic water quality, and in turn about the biogeochemical status of their forested catchments.

\section{ACKNOWLEDGEMENTS}

We would like to thank cordially Eduard Hertel for identifying some difficult bryophyte species. Jörg Schmidt, Petra Peintinger and Ralf Riedel provided unpublished data from their diploma theses. This project was funded by the Bavarian State Ministry of Agriculture and Forestry (board of trustees of the Bavarian State Institute of Forestry LWF, grant L 53), and by the German Federal Ministry of Education and Research (BMBF, grant No. 0339476 D).

\section{REFERENCES}

Alewell, C., M. Armbruster, J. Bittersohl, C.D. Evans, H. Meesenburg, K. Moritz \& A. Prechtel. 2001. Are there signs of acidification reversal in freshwaters of the low mountain ranges in Germany? Hydrol. Earth Syst. Sc., 5: 367-378.

Beierkuhnlein, C. 1994. Waldquellfluren im Frankenwald Untersuchungen zur reaktiven Bioindikation. Bayreuther Forum Ökologie, 10: 1-253.

Beierkuhnlein, C. \& W. Durka. 1993. Beurteilung von Stoffausträgen immissionsbelasteter Waldökosysteme Nordostbayerns durch Quellwasseranalysen. Forstwiss. Centralbl., 112: 225-239.

Beierkuhnlein, C. \& W. Gräsle. 1998. The influence of light regime and water chemistry on the structure of forest spring vegetation. In: L. Botosaneanu (Ed.) Studies in crenobiology: the biology of springs and springbrooks. Backhuys, Leiden: 9-22. 
Bragazza, L. \& R. Gerdol. 2002. Are nutrient availability and acidity-alkalinity gradients related in Sphagnum-dominated peatlands? J. Veg. Sci., 13: 473-482.

Braun-Blanquet, J. 1964. Pflanzensoziologie. Grundzüge der Vegetationskunde. 3. Springer, Wien: $865 \mathrm{pp}$.

Cantonati, M., R. Gerecke \& E. Bertuzzi. 2006. Springs of the Alps - sensitive ecosystems to environmental change: from biodiversity assessments to long-term studies. Hydrobiologia, 562: 59-96.

Church, M.R. 1997. Hydrochemistry of forested catchments. Annu. Rev. Earth Pl. Sc., 25: 23-59.

Ellenberg, H. 1996. Vegetation Mitteleuropas mit den Alpen in ökologischer, dynamischer und historischer Sicht. 5. Ulmer, Stuttgart: $1095 \mathrm{pp}$.

Ferrington, L.C. 1998. Generic composition of the chironomid fauna in springs of North America. In: L. Botosaneanu (Ed.): Studies in crenobiology: the biology of springs and springbrooks. Backhuys, Leiden: 141-155.

Frahm, J.-P. \& W. Frey. 2004. Moosflora. 4. Ulmer, Stuttgart: $538 \mathrm{pp}$.

Glazier, D.S. 1991. The fauna of North American temperate cold springs: patterns and hypotheses. Freshwat. Biology, 26: $527-542$

Hájek, M., P. Hekera \& P. Hájková. 2002. Spring fen vegetation and water chemistry in the Western Carpathian flysch zone. Folia Geobot., 37: 205-224.

Hájková, P., M. Hájek, I. Apostolova, D. Zelený \& D. Díte. 2008. Shifts in the ecological behaviour of plant species between two distant regions: evidence from the base richness gradient in mires. J. Biogeogr., 35: 282-294.

Hinterlang, D. 1992. Vegetationsökologie der Weichwassergesellschaften zentraleuropäischer Mittelgebirge. Crunoecia, 1: 5-117.

Kleber, A., A. Schellenberger, C. Beierkuhnlein, M. Kaupenjohann \& S. Peiffer,. 1998. Slope deposits and water paths in a spring catchment, Frankenwald, Bavaria, Germany. Nutr. Cycl. Agroecosyst., 50: 119-126.

Leduc, A., P. Drapeau, Y. Bergeron \& P. Legendre. 1992. Study of spatial components of forest cover using partial Mantel tests and path analysis. J. Veg. Sci., 3: 69-78.

Legendre, P. \& E.D. Gallagher. 2001. Ecologically meaningful transformations for ordination of species data. Oecologia, 129: 271-280.

Likens, G.E. \& F.H. Bormann. 1999. Biogeochemistry of a forested ecosystem. 2. Springer, New York: $159 \mathrm{pp}$.

Lischeid, G., C. Alewell, J. Bittersohl, A. Göttlein, C. Jungnickel, H. Lange, B. Manderscheid, K. Moritz, B. Ostendorf \& H. Sager. 1998. Investigating soil and groundwater quality at different scales in a forested catchment: the Waldstein case study. Nutr. Cycl. Agroecosyst., 50: 109-118.

McCune, B. \& J.B. Grace. 2002. Analysis of Ecological Communities. MjM Software Design, Gleneden Beach: 300 pp.

Moldan, B. \& J. Černý (Eds). 1994. Biogeochemistry of small catchments - a tool for environmental research. Scope 51, Wiley, New York: 432 pp.

Nekola, J.C. 2004. Vascular plant compositional gradients within and between Iowa fens. J. Veg. Sci., 15: 771-780.

Oberdorfer, E. 2001. Pflanzensoziologische Exkursionsflora für Deutschland und angrenzende Gebiete. 8. Ulmer, Stuttgart: $1056 \mathrm{pp}$.

Odum, E.P. 1971. Fundamentals of Ecology. 3. Saunders, Philadelphia: $574 \mathrm{pp}$

Oksanen, J. 2009. Multivariate Analysis of Ecological Communities in $R$ : vegan tutorial. (http://cc.oulu.fi/ jarioksa/opetus/metodi/vegantutor.pdf) accessed February 2010.
Oksanen, J., R. Kindt, P. Legendre, B. O'Hara, G.L. Simpson, P. Solymos, M.H.H. Stevens \& H. Wagner. 2009. vegan: community ecology package. R package version 1.15-4. (http://r-forge.r-project.org/projects/vegan) accessed October 2009.

Palmer, S.M., C.T. Driscoll \& C.E. Johnson. 2004. Longterm trends in soil solution and stream water chemistry at the Hubbard Brook experimental forest: relationship with landscape position. Biogeochemistry, 68: 51-70.

Peiffer, S., C. Beierkuhnlein, A. Sandhage-Hofmann, M. Kaupenjohann \& S. Bär. 1997. Impact of high aluminium loading on a small catchment area (Thuringian slate mining area) - geochemical transformations and hydrological transport. Water, Air, and Soil Pollution, 94: 401-416.

Probst, A., J.P. Party, C. Fevrier, E. Dambrine, A.L. Thomas \& J.M. Stussi. 1999. Evidence of springwater acidification in the Vosges mountains (north-east of France): influence of bedrock buffering capacity. Water, Air, and Soil Pollution, 114: 395-411.

R Development Core Team. 2009. R: A language and environment for statistical computing. $R$ Foundation for Statistical Computing. Vienna, Austria. (http://www.R-project.org) accessed October 2009.

Rantakari, M., P. Kortelainen, J. Vuorenmaa, J. Mannio \& M. Forsius. 2004. Finnish lake survey: the role of catchment attributes in determining nitrogen, phosphorus, and organic carbon concentrations. Water, Air, and Soil Pollution: Focus, 4: 683-699.

Reuss, J.O., B.J. Cosby \& R.F. Wright. 1987. Chemical processes governing soil and water acidification. Nature, 329: 27-32.

Steinberg, C.E.W. \& R.F. Wright (Eds). 1994. Acidification of freshwater ecosystems. Wiley, Chichester: $404 \mathrm{pp}$.

Stoddard, J.L., D.S. Jeffries, A. Lükewille, T.A. Clair, P.J. Dillon, C.T. Driscoll, M. Forsius, M. Johannessen, J.S. Kahl., J.H. Kellogg, A. Kemp, J. Mannio, D.T. Monteith, P.S. Murdoch, S. Patrick, A. Rebsdorf, B.L. Skjelkvale, M.P. Stainton, T. Traaen, H. van Dam, K.E. Webster, J. Wieting \& A. Wilander. 1999. Regional trends in aquatic recovery from acidification in North America and Europe. Nature, 401: 575-578.

Strohbach, M., V. Audorff \& C. Beierkuhnlein. 2009. Drivers of species composition in siliceous spring ecosystems: groundwater hydrochemistry, catchment traits or spatial factors? J. Limnol., 68: 375-384.

Tahvanainen, T. 2004. Water chemistry of mires in relation to the poor-rich vegetation gradient and contrasting geochemical zones of the north-eastern Fennoscandian shield. Folia Geobot., 39: 353-369.

Thienemann, A. 1924. Hydrobiologische Untersuchungen an Quellen. Arch. Hydrobiol., 14: 151-189.

Vitt, D.H. \& W.-L. Chee. 1990. The relationships of vegetation to surface water chemistry and peat chemistry in fens of Alberta, Canada. Vegetatio, 89: 87-106.

Wheeler, B.D. \& M.C.F. Proctor. 2000. Ecological gradients, subdivisions and terminology of north-west European mires. J. Ecol., 88: 187-203.

Williard, K.W.J., D.R. Dewalle \& P.J. Edwards. 2005. Influence of bedrock geology and tree species composition on stream nitrate concentrations in mid-Appalachian forested watersheds. Water, Air, and Soil Pollution, 160: 55-76.

Zollhöfer, J.M., M. Brunke \& T. Gonser. 2000. A typology of springs in Switzerland integrating habitat variables and fauna. Arch. Hydrobiol. Suppl., 121: 349-376. 